\title{
Service innovation and internationalization in SMEs: antecedents and profitability outcomes
}

\section{Anna Vuorio ${ }^{1} \cdot$ Lasse Torkkeli $^{1}$ (D) $\cdot$ Liisa-Maija Sainio $^{1}$}

Published online: 13 January 2020

(C) The Author(s) 2020

\begin{abstract}
Both innovating and internationalizing can hold the key to survival and growth among small- and medium-sized enterprises (SMEs). Service innovation in particular is highly relevant in the increasingly digitalized and high-technology global trade. However, there have been until now few studies on service innovation in international entrepreneurship. Thus, in an effort to illuminate its role in entrepreneurial internationalization, the present study examines the profitability impact of service innovation in SME internationalization, while also outlining the differing impacts of entrepreneurial orientation and human capital as the antecedents of both. The empirical data were collected via an online survey of Finnish SMEs in the information and communications technology (ICT) industrial sector, the final sample comprising 104 companies. The data were analyzed through structural equation modeling. The results indicate, first, that entrepreneurial orientation underlies both degree of internationalization and service innovation, yet different dimensions of entrepreneurial orientation have distinct impacts on the two outcomes. Second, we find that the level human capital also determines the level of service innovation in as an antecedent and third, international expansion, but not service innovation, has a negative impact on profitability. We discuss the implications of these results, which imply that SMEs may face an internationalizationinnovation paradox in that engaging in both activities may not be a feasible strategic option for them, and that prioritizing internationalizing in favor of innovating may incur costs and result in lower profitability.
\end{abstract}

Lasse Torkkeli

lasse.torkkeli@lut.fi

Anna Vuorio

anna.vuorio@lut.fi

Liisa-Maija Sainio

liisa-maija.sainio@lut.fi

1 School of Business and Management, LUT University, Yliopistonkatu 34, 53850 Lappeenranta, Finland 


\section{Resume}

La investigación académica ha mostrado como la innovación y la internacionalización son impulsos importantes de la sostenibilidad y el crecimiento entre las pequeñas y medianas empresas (PYMES). En este contexto, la innovación orientada a los servicios es particularmente relevante, sobre todo en un contexto de desarrollo tecnológico y digitalización en los mercados globales. No obstante, no existe mucha investigación sobre innovación en servicios en el marco del emprendimiento internacional. En este artículo, los autores tienen como objetivo estudiar el papel de la innovación en servicios en el marco del emprendimiento internacional, analizando aquellas empresas emprendedoras que aspiran a los mercados internacionales. El articulo analiza la rentabilidad de la innovación en servicios en la internacionalización de las PYMES, a la vez que estudia diferentes impactos de la orientación empresarial y el capital humano como antecedentes de ambos, innovación en servicios y internacionalización. El estudio analiza datos empíricos recogidos a través de una encuesta online distribuida a PYMES finlandesas en el sector de la información y la comunicación. La muestra final comprende 104 empresas. Los datos se analizan con modelos de ecuaciones estructurales. Los resultados indican diferentes aspectos importantes para avanzar el conocimiento. Primero, que la orientación emprendedora impulsa tanto el grado de internacionalización, como la innovación en servicios, de forma que las diferentes dimensiones de la orientación emprendedora tienen diferentes impactos en los dos. Segundo, el nivel de capital humano influye también el nivel de innovación en servicios como antecedente. Tercero, la expansión internacional, sin la innovación en servicios, tiene un impacto negativo en la rentabilidad. En la discusión se presentan las implicaciones de estos resultados, que implican que la PYMES pueden padecer una paradoja entre la internacionalización y la innovación cuando intentan unificar el desarrollo de las dos actividades. Estos resultados informan sobre el hecho que las dos actividades conjuntas pueden resultar una no adecuada opción estratégica. Además, cabe destacar que priorizar la internacionalización puede resultar en costes y menor rentabilidad.

Keywords Internationalization of SMEs · Innovation in SMEs · Service innovation · Entrepreneurial orientation $\cdot$ Human capital $\cdot$ Profitability

\section{Summary highlights}

Contributions: The study contributes to the international entrepreneurship literature by examining entrepreneurial internationalization and service innovation, more specifically their drivers and performance implications. Literature is still mixed about the relationship between entrepreneurial internationalization and innovation, and their relationship has been suggested to be innovation type specific. However, the prior research has mostly overlooked service innovation, which is important in knowledgeintensive industry sectors in particular. The study sheds further light on the role of entrepreneurial orientation (EO) and human capital as drivers of entrepreneurial internationalization in the context of service innovation.

Purpose: This study explores the relationship between entrepreneurial internationalizing and service innovation by analyzing jointly the effects that the extent of service innovation and degree of internationalization (DOI) have on the profitability of 
internationalizing SMEs, as well as the effects that entrepreneurial orientation (EO) and human capital have on both innovation and internationalization.

Data: The data were collected via an online survey of Finnish SMEs operating in the ICT industrial sector. The structured survey consisted of measurement scales adopted from the prior literature. A total of 104 Finnish ICT SMEs comprised the sample utilized in this study.

Findings/Results: On the impact of entrepreneurial orientation dimensions, the results show that innovativeness has a negative effect on DOI but a positive effect on service innovation. Proactiveness is not connected to service innovation or internationalization, while risk-taking has a positive effect on DOI but not on service innovation. The skills and know-how element of human capital is positively connected to higher extent of service innovation. The results also highlight that international expansion may hinder a firm's financial performance, since DOI had a negative effect on profitability. Taken together, the results imply that firms may have to make trade-offs when choosing between international expansion and service innovation, and that the dimensions of entrepreneurial orientation underlie internationalization and service innovation differently.

Theoretical implications and recommendations: The study indicates that service innovation focus in internationalizing SMEs may generate benefits; however, accumulating these benefits may be complex and directed by the firm's strategic goals. Additionally, the results suggest that, depending on their strategic goals, SMEs seeking internationalization may need to compromise on being innovative with their services. Thus, by examining DOI and service innovation and their drivers simultaneously, the study adds to the discussions on entrepreneurial internationalization and innovation.

Practical implications and recommendations: The study highlights the necessity of strategic focus for internationalizing SMEs by suggesting that dual strategy on innovation and internationalization is not always beneficial, especially if the aim of the internationalizing SME is to maintain profitability. Additionally, the study highlights the importance of top management skills and knowledge in enhancing both innovation and internationalization. The results suggest that internationalizing SMEs that also engage in service innovation in particular need to invest in training to improve the skills and knowledge of top management.

Limitations and future research: The study is limited to a single country, a single industry and a cross-sectional nature of data, and thus the findings of the study may have limited generalizability across different contexts. Future research could include cross-country data across other knowledge-intensive industries. Further insights on the DOI-profitability relationship could be generated longitudinally via panel data. Another avenue for future research is extending the unit of analysis from the organization level to that of the individual.

\section{Introduction}

The development of small- and medium-sized enterprises (SMEs) is essentially influenced by the extent of their success in innovation and internationalization (Louart and 
Martin 2012; Hagen et al. 2014), and innovative SMEs are more likely to export than non-innovative SMEs (Saridakis et al. 2019). Innovative organizational culture is linked to rapid entry into foreign markets (Knight and Cavusgil 2004; Jones and Coviello 2005; Chetty and Stangl 2010; Onetti et al. 2012). McDougall and Oviatt (2000, p.903) already incorporated innovation and internationalization into the very definition of international entrepreneurship (IE), i.e., "a combination of innovative, proactive and risk-seeking behavior that crosses national borders and is intended to create value in organizations". This definition brings an international dimension to the concept of entrepreneurial orientation (Covin and Slevin 1989, 1991; Lumpkin and Dess 1996; Miller 2011), and later studies have indeed identified positive linkages between higher levels of entrepreneurial orientation (EO) and internationalization decisions, activities, and performance in SMEs (Jantunen et al. 2005; Kuivalainen et al. 2007; Ripollès-Melià et al. 2007). However, extant studies have also left several aspects of entrepreneurial internationalization and innovation relatively unexamined.

One such area relates to clarifying the relationship between entrepreneurial internationalization and innovation further. The two have been found to be intertwined (Onetti et al. 2012; Denicolai et al. 2015), but whether innovation is a driver of internationalization (Golovko and Valentini 2011; Veglio and Zucchella 2015; Calvo and Villarreal 2019; Weerawardena et al. 2019) or rather, if the opposite is the case (Kafouros et al. 2008; Zahra et al. 2009; Genc et al. 2019; Vrontis and Christofi 2019) and under which conditions, could do with further study as the extant literature has found both types of relationships, and the linking literature overall is of recent origin (Hagen et al. 2014). As Veglio and Zucchella (2015, p. 139) note, there are studies on the dynamics of innovation and internationalization, but mostly from the context of large companies (see CanoKollmann et al. 2016). Recently, Saridakis et al. (2019) have found that the link between innovation and internationalization is also dependent on the type of innovations, and Weerawardena et al. (2019) posit that learning capabilities can underlie the development of innovation in born globals. Bello et al. (2016) also recently examined how innovativeness of service offerings relates to financial performance, but that study did not account for internationalization, which we in this study aim to do.

Specifically, the antecedents and outcomes of internationalization- and innovationrelated activities in SMEs should be clarified further in order to establish what types of trade-offs do SMEs have to consider in their internationalization and innovation efforts: Although both internationalization and innovation activities may reside in the organizational culture (Dimitratos and Plakoyiannaki 2003), in practice, a SME may not have the resources necessary to engage seriously in both simultaneously. Indeed, innovativeness may, in some cases, hinder internationalization efforts (Dai et al. 2013). Such a situation presents SMEs with the necessity of trade-offs.

Second, extant studies examining innovation in the context of SME internationalization tend to examine different types of innovativeness, namely product innovation (e.g., Zahra et al. 2009), design innovation (Veglio and Zucchella 2015), and business model innovation (Rask 2014). However, the role of service innovation in the context has received very little attention so far (Weerawardena et al. 2019). This is despite the fact that service innovation as concept that has performance implications (Bello et al. 2016), is distinct scientifically, and offers promise for cross-disciplinary research in particular (Karniouchina et al. 2006). Instead, research on entrepreneurship and innovations in general has tended to be mostly limited on examining product innovations 
instead (Oly Ndubisi 2014). As internationalization can be related to the type of innovation in question (Denicolai et al. 2015; Saridakis et al. 2019), examining the role of service innovation in international entrepreneurship can bring forth added knowledge to complement and extend the extant studies concentrating on different types of innovations (Rask 2014; Veglio and Zucchella 2015).

Indeed, a large portion of entrepreneurial internationalization occurs in hightechnology fields where service innovation is a core element in corporate decisionmaking (Van Riel et al. 2004). This is particularly the case with born globals (Rennie 1993; Madsen and Servais 1997), which tend to be knowledge-intensive in nature (Kuivalainen et al. 2012) and to operate in service-oriented industrial sectors such as software (Bell 1995). There is thus a clear need to examine the role of service innovation in international entrepreneurship.

This study aims to respond to these omissions in literature, by illustrating the relationships between service innovation and internationalization on successful entrepreneurial internationalization. As most existing studies have not assessed both the antecedents and the related outcomes of internationalization and innovation in general, we also explore the antecedents of both the service innovation (SI) and international expansion in SMEs, and link the two to performance outcomes, namely to profitability. This is due to earlier literature examining the impact of international expansion on business performance having reported contradictory and ambiguous results (see, e.g., Capar and Kotabe 2003; Lu and Beamish 2004; Thomas and Eden 2004), and most of the studies in question having been conducted in manufacturing contexts (Capar and Kotabe 2003). Only a few studies in IE assess the profitability aspect of internationalizing SMEs, and those that do give conflicting results ( $\mathrm{Lu}$ and Beamish 2001, 2006; Qian and Li 2003; Zhou et al. 2007). Thus, there is also a need for further clarification on the relevant question of how internationalization affects the profitability of SMEs. Given that engaging in both internationalization and innovation may stretch the financial and other resources of SMEs, which by nature are resource-constrained to begin with (Madsen and Servais 1997), maximizing profitability may be of the essence for an innovating SME aiming for both foreign-market entry and long-term survival.

The extant literature identifies two concepts in particular that may, in part, underlie and determine the extent of both service innovation and internationalization: human capital (Becker 1964; Youndt and Snell 2004) and entrepreneurial orientation (Miller 1983; Covin and Slevin 1989). Genc et al. (2019) have recently posited that entrepreneurial orientation can mediate a relationship between internationalization and innovation performance, while the study by Bello et al. (2016) finds that entrepreneurial orientation and human capital predict the innovativeness of service offering in Indian professional service firms. While the latter study did not account for internationalization in their empirical model, it does provide the basis for postulating on these antecedents of service innovation also in international entrepreneurship. In general, both human resources of SMEs and their entrepreneurial orientation have been found to drive business performance (Grimmer et al. 2013). However, there is only limited amount of research examining causal relationships between entrepreneurial orientation and the multitude of outcomes, e.g., firm profitability, international scope, and product development performance, to which it has been connected (Wales et al. 2013).

Therefore, this study examines the impact of human capital (HC) and entrepreneurial orientation (EO) on internationalization and service innovation of SMEs, and the 
subsequent impact of the latter two on the profitability of internationally operating SMEs. We continue as follows: Sect. 2 gives a more in-depth literature review of the relevant research, examining the theoretical foundations underlying the proposed relationships between the antecedents of DOI and SI and their profitability outcomes; Sect. 3 introduces the research methodology and describes the data collection procedure and the measures we developed; Sect. 4 gives the empirical results, and we conclude in Sect. 5 with a discussion of their implications and limitations, also identifying potential future research avenues.

\section{Hypothesis development}

\section{Entrepreneurial orientation as an antecedent in SME internationalization and service innovation}

Innovativeness is part of entrepreneurial orientation, and the relationship of the latter with internationalization has also been under literary focus for some time and is particularly relevant for performance implications in IE (see Etemad 2015). SME internationalization has been interpreted specifically as an act of EO, in other words an expansion strategy to enter new markets by seeking growth opportunities (Lumpkin and Dess 1996; Zahra et al. 1999; Ripollès-Melià et al. 2007). Furthermore, small companies facing resources constraints and dynamic operational environment overcome their deficiencies through EO and innovation (Cavusgil and Knight 2015).

Entrepreneurial orientation has been conceptualized as a set of managerial behaviors or attitudes, or a combination of both (Miller 2011). Miller suggests examining EO as a multidimensional construct (i.e., comprising risk-taking, proactiveness and innovativeness), as each of the dimensions may vary in their impact on innovation- and internationalization-related activities (Kuivalainen et al. 2007; Frishammar and Andersson 2009; Harms et al. 2010). Other studies have previously also supported the idea that EO is a multidimensional construct (e.g., Covin and Slevin 1990; Miller 1983; Wiklund 1999). EO includes the decision-making operations, processes, and practices that result in expansion in markets, products, or services, or in all three (Lumpkin and Dess 1996). It is also described as a strategic orientation that reflects specific entrepreneurial facets of company-level outcomes, decision-making styles, methods, and practices, as well as managerial behavior, beliefs, and preferences (Covin et al. 2006; Lumpkin and Dess 1996). EO reflects the degree of top management's willingness to take business risks and pursue change and innovation to respond actively to competition and sustain competitive advantage (Covin and Slevin 1990). The entrepreneurial propensity for proactiveness, risk-taking, and innovativeness is also a medium through which EO can be examined (Runyan et al. 2008).

Innovativeness and proactiveness are prerequisites for expansion into international markets (Fletcher 2004; Knight and Cavusgil 2004). Moreover, the combination of a willingness to take risks and innovativeness is an essential feature of successful operations in global markets (McDougall and Oviatt 2000). These features are considered part of EO, the implication being that international operations are entrepreneurial (Fletcher 2004). The ability to identify and utilize opportunities in foreign markets is more marked in companies with an innovative culture and capabilities (Jantunen et al. 2005; Lazonick 2005). EO both tends to strengthen the intent of a company to 
internationalize (De Clercq et al. 2005) and further serve as an antecedent of innovation activities in SMEs. Some studies report a positive relationship between the level of EO and innovations (Rhee et al. 2010; Pèrez-Luno et al. 2011; Asemokha et al. 2019), and Hult et al. (2004) specifically argue that the key driver of innovativeness and performance in companies is the extent of their EO. Recently, innovativeness has been positively connected to speed of innovation, while risk-taking has a negative effect on speed of innovation (Shan et al. 2016). Additionally, increases in proactivenss increase the speed of innovation to a certain point, beyond which it actually decreases the speed.

There is evidence of a relationship between EO and foreign market expansion in SMEs from both emerging (Javalgi and Todd 2011) and developed economies (Ripollès-Melià et al. 2007; D'Angelo and Presutti 2019). EO has been found to be positively associated with degree of internationalization (DOI), the number of foreign countries a company has entered (Javalgi and Todd 2011), international sales growth (D’Angelo and Presutti 2019), and foreign entry success (Baker et al. 2019). Wiklund et al. (2009) note a positive effect of EO on growth in small businesses, whereas Frishammar and Andersson (2009) found that proactiveness had an impact on the international performance of Swedish SMEs. Entrepreneurially oriented activities and internationalization are dual processes that companies integrate in practice when aiming to conduct business internationally (Fletcher 2004).

The majority of extant studies indicate that EO strengthens a company's intent to internationalize, and that the likelihood of further internationalization is higher among companies with high EO. Risk-taking and innovative thinking or proactive expansion to new markets may to some degree determine a company's international success and the extent of its presence in foreign markets (De Clercq et al. 2005). Moreover, the early development of an entrepreneurial culture enhances the ability and willingness to pursue international opportunities (Autio et al. 2000; Zucchella et al. 2007). In accordance with these notions, we first posit that

- H1: Higher levels of entrepreneurial orientation among international SMEs are positively related to their degree of internationalization.

H1a: Higher levels of innovativeness among international SMEs are positively related to their degree of internationalization.

$\mathrm{H} 1 \mathrm{~b}$ : Higher levels of proactiveness among international SMEs are positively related to their degree of internationalization.

H1c: Higher levels of risk-taking among international SMEs are positively related to their degree of internationalization.

Several definitions of service innovation (SI) are to be found in the literature (Gadrey et al. 1995; Gallouj and Weinstein 1997; Avlonitis et al. 2001; Alam 2006; Paswan et al. 2009). It is seen as an evolutionary process of dynamically combining and recombining diverse elements to meet customer needs (Chae 2011), and as a completely new or significantly renewed service that generates benefits to its developer and can be replicated with numerous customers (Toivonen and Tuominen 2009). Damanpour (1991) distinguishes service innovation as one of the main innovation types in addition to product and process innovation types, among others. 
Entrepreneurial orientation may be linked to SI in various ways. It drives the innovativeness and innovative activities that an individual or an organization can generate on the company level (Naman and Slevin 1993; Lumpkin and Dess 1996; Hult et al. 2004). Engagement in creating innovations that are new to the market and a willingness to undertake ventures that carry considerable risk are also characteristics of an entrepreneurial company (Miller 1983). Such companies are also active in seeking opportunities to develop new technologies, products, and services and to engage in both innovation generation and adaptation (Damanpour and Wischnevsky 2006). Bello et al. (2016) find evidence for entrepreneurial orientation underlying innovativeness of Indian professional service firms in general.

There is also empirical evidence of a positive relationship between EO and innovations in general. Zhou et al. (2005) found a positive association with both technology- and market-based innovations, and a positive relationship has also been identified in German companies (Harms et al. 2010). Hult et al. (2003), in turn, found that the role of EO in the tendency to innovate was significant among old service- and product-oriented companies regardless of their size. EO also influences product innovativeness through the acquisition of new information in the process of developing new products (Brockman and Morgan 2003).

The focus on innovation is a fundamental aspect of EO, although proactiveness and risk-taking are also important (Harms et al. 2010). There is some evidence of how each dimension influences innovations. For instance, proactiveness and risk-taking have a positive impact on innovation generation, and strongly drive companies to prefer generation to adaptation (Pèrez-Luño et al. 2011). A company's willingness to abandon current practices and technologies and to go beyond existing standards is also reflected in innovativeness (Kimberly 1981). Furthermore, some scholars suggest that each of the EO dimensions may affect innovation and internationalization differently (Kuivalainen et al. 2007; Frishammar and Andersson 2009; Harms et al. 2010). We posit that these notions hold in service innovation among SMEs as well:

- H2: Higher levels of entrepreneurial orientation among international SMEs are positively related to their level of service innovation.

H2a: Higher levels of innovativeness among international SMEs are positively related to their level of service innovation.

$\mathrm{H} 2 \mathrm{~b}$ : Higher levels of proactiveness among international SMEs are positively related to their level of service innovation.

H2c: Higher levels of risk-taking among international SMEs are positively related to their level of service innovation.

\section{Human capital as an antecedent in SME internationalization and service innovation}

Human capital comprises the knowledge individuals possess and take with them when they go home from work. It constitutes skills, experiences, abilities, and know-how, including innovation capacity, creativity, formal training, and education (Marr et al. 2004) and, according to Barney (1991), company resources in the form of management-worker relationships, intelligence, judgment, and insight. Firm-specific, 
industry-specific, and general levels of human capital have been described (Neal 1995; Huang 2003), and a two-dimensional structure based on employee skills and expertise on the one hand and their creativity and new ideas on the other have been recognized (Youndt et al. 2004).

On the individual level, human capital is the combination of a person's genetic inheritance, education, experience, and attitudes to life and business (Hudson 1993). It could be considered an essential enabler of internationalization in general, and of the extent of international operations in particular: studies have repeatedly identified a positive link between the two (e.g., Bloodgood et al. 1996; Reuber and Fischer 1997; Ruzzier et al. 2007; Javalgi and Todd 2011). This further attests to the importance of human resources for SMEs: human capital compensates for the lack of other resources (Westhead et al. 2001; Radulovich 2008). Conversely, a lack of human capital may constitute a further barrier to internationalization (Dichtl et al. 1990). The humancapital resources of entrepreneurial companies, including the entrepreneurs themselves, positively affect their propensity to export (Westhead et al. 2001).

Similarly, human capital has been positively associated with the ability of companies to innovate (Martin and Horne 1995; de Brentani 2001; Oke 2007), and there is evidence of a significant impact on innovation in high-technology SMEs (e.g., Acs 1999; Qian and Li 2003; Thornhill 2006; Wu et al. 2008) and on professional service firms in particular (Bello et al. 2016). Thus, even though no studies examining the two have been conducted to our knowledge, extant literature does provide some grounds to posit that human capital could well be a determinant of both DOI and SI,

Managerial skills and environmental perceptions are the most important dimensions of human capital (Manolova et al. 2002). Onkelinx et al. (2016b) find a positive curvilinear relationship between human capital and SME internationalization, yet their analysis concentrates on export performance only. Investments in human capital may be necessary for born globals and other rapidly internationalizing enterprises in particular (Onkelinx et al. 2016a). In a recent study, Silva et al. (2017) also noted human resources as an important factor in export performance of internationally operating firms. Moreover, previous international experience and positive foreign-market perceptions of the owner/founder increases the likelihood of internationalization and further foreign expansion, given the high odds that owners and/or founders have to rely on their international experience, competences, and skills when internationalizing (Manolova et al. 2002; Ruzzier et al. 2007). Thus, we suggest that human capital may be positively associated with international expansion among SMEs:

- H3: Higher levels of human capital among internationally operating SMEs are positively related to their degree of internationalization.

A company's employees play a crucial role in the innovation process, being the generators of ideas for new or improved services that turn into successful innovations (Van de Ven 1986). Frontline employees tend to be the ones who recognize innovation opportunities and are aware of unsatisfied customer needs; thus, their inclusion in the process may increase the likelihood of success in implementing service innovations (de Brentani 2001). Innovative service companies seeking a solution to an existing innovation challenge need the knowledge, skills, and other similar resources that, in combination, constitute the capabilities of the service innovator (Kuusisto et al. 
2013). Successful companies use highly skilled and trained personnel in both frontline and production activities in the process of creating and delivering new services (de Brentani 2001).

Human resources, which comprise interpersonal and business skills, are positively related to the innovation strategy in small firms (Edelman et al. 2005). Veglio and Zucchella (2015) note that small firms can develop certain innovations without necessarily making large other types of resource commitments if they leverage the creativity of the employees and entrepreneurs. Long-term customer interaction, creative employees, and solid technical and marketing skills are required from companies with an innovation strategy (Chandler and Hanks 1994), and those with successful service innovations seem to encourage higher overall internal participation in the process (Martin and Horne 1995). Professional knowledge possessed by employees and based on education and experience positively correlates with a firm's innovations (Damanpour 1991). There is also evidence that investing in human capital has an impact on innovations: in-service training appears to have a positive effect (Ballot et al. 2001; Gallie and Legros 2012).

Human capital is also positively related to the creation of sustained competitive advantage (Ordeñez de Pablos 2004). This is achieved in international companies through the integration of knowledge-based resources from different units, which in turn describe the organization's capacity to innovate (Ordeñez de Pablos 2006). The role of industry-specific knowledge is especially important when innovation ideas are generated through combining collaboration with network partners and tacit knowledge of existing technology (Dakhli and De Clercq 2004).

Employees in high-tech SMEs in particular tend to be more innovative than those in large companies on account of the clearer property rights (Acs and Yeung 1999; Qian and Li 2003). Furthermore, the resources of high-tech SMEs, including specialized expertise and previous experience, positively affect their competitiveness, including innovation speed (Wu et al. 2008). Given that the knowledge possessed by people in an organization is the key to creating innovations, human capital may have an impact on SI (Bello et al. 2016). We therefore suggest, based on the literature discussed above, that this influence also extends to internationalizing SMEs.

- H4: Higher levels of human capital among international SMEs are positively related to their level of service innovation.

\section{The impact of internationalization and service innovation on the profitability of SMEs}

A major prerequisite for successful internationalization among SMEs is the ability to develop new products and services (Bell et al. 2004). There are two main reasons why a positive relationship between service innovation and profitability could be expected in internationally operating SMEs: first-mover advantage and performance gap (Ettlie 1983; Lieberman and Montgomery 1988; Roberts and Amit 2003; Damanpour et al. 2009). First-mover advantage is achieved through innovations and thus may enhance business performance (Roberts and Amit 2003), whereas a performance gap results from a change in the environment to which the company is able to adapt by innovating (Ettlie 1983). 
Moreover, radical innovations enhance financial performance in dynamic environments such as international markets (Saridakis et al. 2019), whereas incremental innovations have the same effect in competitive environments (Jensen et al. 2006). Companies that absorb novel knowledge are more conscious about the most recent developments, and in achieving first-mover position through innovation activities are more likely to exploit the benefits thus generated in the long term (Cohen and Levinthal 1990; Roberts and Amit 2003). Earlier research points towards a positive relationship between innovations and overall company performance (Cainelli et al. 2004, 2006; Freel and Robson 2004; Damanpour et al. 2009).

Forthcoming research has linked R\&D innovation to international expansion (Vrontis and Christofi 2019) and highlighted the importance of service innovation for born globals in particular (Calvo and Villarreal 2019; Weerawardena et al. 2019). The capacity to pursue innovation has a positive impact on profitability, sales growth, market share, and general performance in general (Hult et al. 2004). Moreover, performance is influenced by innovations in global markets (Hitt et al. 1998). Innovator position may have a positive influence on profitability among SMEs in particular (Qian and $\mathrm{Li}$ 2003). It has also been found that technology-focused service sectors, including software, technical consultancy, $R \& D$, engineering, and post and telecommunication are more innovative than other service sectors (Cainelli et al. 2004, 2006). Therefore, we posit the following:

- H5: The level of service innovation in international SMEs is positively related to their profitability.

Empirical findings on the relationship between DOI and overall business performance are inconsistent and conflicting (Annavarjula and Beldona 2000; Lu and Beamish 2004). In theory, a positive relationship between DOI and profitability could be expected in an SME, in that exploration and exploitation benefits through geographical expansion may allow advantage to be taken of learning, and of economies of scale and scope (Kogut 1985; Lu and Beamish 2004). Moreover, companies can benefit from cost differences through internationalization, as well as minimize their costs by using local expertise (Kogut 1985; Ghoshal 1987; Thomas and Eden 2004).

However, it may well be that the rising costs of internationalization exceed the initial benefits: costs attributable to managerial and resource constraints arise because the need for coordination and communication increases as DOI increases (Qian 2002). Although it is suggested that SMEs could benefit more from increased DOI than large companies (Loth and Parks 2002), there is some evidence of a negative effect of foreign-market expansion on SME profitability (Lu and Beamish 2001, 2006), although other scholars have found a positive relationship (Qian and Li 2003; Zhou et al. 2007; Kuivalainen et al. 2007; Schwens et al. 2017). Finally, Zahra et al. (2000) suggest that the nature of this relationship may depend on the characteristics of the company. One such influence may be the original location of the firm, as SMEs from small open economies tend to be faced with small domestic markets, which further pushes them to internationalize (Madsen and Servais 1997). Inherent in internationalization in this context is the need to incur additional risks, to aggressively commit resources in order to grow foreign operations, and to balance that risk with internal 
innovation activities in the company, such as service innovation. Given their prevalence in the research on international entrepreneurship, we have chosen such SMEs as our empirical context, and thus posit that:

- H6: The level of DOI in internationally operating SMEs is negatively related to their profitability.

\section{Research methodology}

\section{Data collection}

We collected our data via an online survey of Finnish SMEs operating in the ICT industrial sector. Our choice of this specific context was based on theoretical, managerial, and societal considerations. First, the role of human capital is recognized as important in both SMEs in general and in ICT companies in particular (Bloodgood et al. 1996; Manolova et al. 2002; Delgado-Gomez et al. 2004; Reuber and Fischer 1997; Ruzzier et al. 2007; Javalgi and Todd 2011). The majority of Finnish ICT companies are small- and medium-sized, and the industry has been characterized as innovative on a global scale: between 2004 and 2009, the percentage of ICT-related patents among the national total was the second highest in the world (OECD 2012). The ICT industry has been characterized as global, and global standards in telecommunications, for example, are emerging, which pushes companies to internationalize early on in order to avoid falling behind their competitors (Bell 1995; Coviello and Munro 1997; Saarenketo et al. 2004). Additionally, innovating in a high-tech sector is necessary to increase the probability of survival (Cefis and Marsili 2006). Thus, specialization, high up-front $R \& D$ costs, and the need to exploit opportunities to the full push companies towards internationalization in order to grow (Saarenketo et al. 2004).

Second, ICT is one of the most innovative sectors in the EU, and the main way for companies to grow is through internationalization (Moen et al. 2004; Saarenketo et al. 2004; Wiig Aslesen 2008). Finland is among the leading countries globally in terms of ICT activities (Dutta and Bilbao-Osorio 2012, 12), and the industry has been the locomotive driving economic development in the country. Given the significant and broad impact of these trends, the attention paid to service innovation has been small compared with that given to technological innovation. Third, within the EU, SMEs comprise $99.8 \%$ of non-financial enterprises and provide $67.4 \%$ of jobs within the nonfinancial business economy (Ecorys 2012, p. 9). For all these reasons, ICT and the SME perspective combined constitute a relevant research context.

We used the European Commission classification of SMEs and ICT firms to identify companies to contact that would be suitable for the purpose of the research. Identified through the Amadeus database, the firms were subsequently sent a cover letter via email with a link to the survey. The questionnaire was pretested on two managers in different fields, and some alterations to the wording of the questions were made based on their suggestions. It was sent to companies in two parts, and the non-respondents were contacted by means of three reminder emails. The questionnaire was sent to 1050 companies representing ICT service, trade, and manufacturing sectors. Four companies 
were excluded from the sample because they did not have international operations. Moreover, 34 companies had blocked the online service that was used to send the survey invitation, and sent e-mails bounced back from eight companies. In all, responses were received from 1004 firms, the three reminder e-mails being sent subsequently to non-respondents. During the 2 months of data collection, 104 filled questionnaires were received, thus resulting in a response rate of $10 \%$. The relatively low response rate could relate to the questions regarding profitability, in which SMEs tend to consider sensitive information (Autio et al. 2000). However, as Rutherford et al. (2017) have pointed out, lower response rates in general do not bias empirical results in entrepreneurship research.

The majority of companies (87.2\%) involved in the research were small-sized, employing less than 50 people (see Table 1). Of these, $63.2 \%$ were micro enterprises with less than 10 employees. The turnover of $79.7 \%$ of the companies was less than five million Euros, the average age was 13 years, and the firms had begun their internationalization activities, on average, in 2005. The majority of the respondents $(76.6 \%)$ were CEOs, with half of them having 8 or more years of international experience, and $34.6 \%$ with more than 15 years. Finally, $42 \%$ of the respondents had been with their current employer for 2 to 4 years, and $24 \%$ for 11 or more years.

We used Likert-scaled items to measure EO, human capital, and SI. The EO measure consisted of nine items, adopted from Jantunen et al. (2005) and based on the original scale of Miller (1983), and Covin and Slevin (1989). This scale and its variations have been commonly used in EO studies, and it has been suggested that the variance in results is not attributable to the use of a certain EO scale (Rauch et al. 2009). We used the nine-item scale because it allows the formation of three dimensions of EO, the usage of which is recommended in the literature (Naman and Slevin 1993; Lumpkin and Dess 1996; Miller 2011; Cadogan 2012). The innovativeness, proactiveness, and risk-taking dimensions were each measured on a set of three items (as seen in Appendix).

Several constructs are used in the literature to describe DOI. Ramaswamy et al. (1996), as well as Sullivan (1994), suggest using multidimensional measures because

Table 1 Respondent demographics. $M$ manufacturing, $W$ wholesale, $S$ service, Internationalization = Year of internationalization, Industry exp. = Industry experience, and Intern.exp. = International experience

\begin{tabular}{lllll}
\hline & & Small & Medium & Missing \\
\hline Amount & $\mathrm{M}$ & 68 & 10 & 22 \\
Industry & $\mathrm{W}$ & 3 & 0 & \\
& $\mathrm{~S}$ & 55 & 0 & \\
Turnover (M€) & & $0.5-0.99$ & 9 & 22 \\
Size & 1.5 & $10-24.9$ & 23 \\
Age & 13 & 4.8 & 24 \\
Internationalization & 2005 & 18 & 36 \\
Industry exp. (years) & & $11-15$ & 2003 & 23 \\
Intern. exp. (years) & $8-10$ & $11-15$ & 24 \\
\hline
\end{tabular}


single-item measures may not fully capture the concept ( $\mathrm{Li}$ 2007). We followed this suggestion. Service innovation was measured on six items adapted from Cooper and Kleinschmidt (1987), which have also been used in service contexts (e.g., AtuaheneGima and Ko 2001; Radulovich 2008). We used a subjective scale to measure profitability, asking the respondents to assess the profitability of their company over the past 3 years relative to their competitors on a seven-point Likert scale (again, as seen in Appendix).

The survey also inquired into company size (total sales and the number of full-time employees). We included questions about the primary sector of operations in order to differentiate between manufacturing and service SMEs, and asked about the age and the international and industry experience of the companies so as to assess the potential impact on internationalization and innovation (Andersson 2000; Manolova et al. 2002; Reuber and Fischer 1997; Ruzzier et al. 2007).

\section{Measures}

We applied factor analysis to determine the reliability and validity of our scales, as it is an appropriate method when partial correlations are small. Partial correlations comprise the basis of Kaiser's measure of sampling adequacy (MSA), which should have a value above 0.5 to be adequate (Hair et al. 1998, p. 99). Varimax rotation is a common rotation method aimed at simplifying the data structure and creating uncorrelated factors: the item communalities can be considered high if they are all 0.8 or greater, and low if they are less than 0.4 (Costello and Osborne 2005). As Table 2 shows, all the resulting factor analyses were reliable, with Cronbach's alpha values of above 0.7 , as Hair et al. (1998) recommend.

As predicted, the rotated factor pattern for EO depicted in Table 2 yielded a threedimensional construct, consisting of innovativeness, risk-taking, and proactiveness. As Table 2 also shows, the overall MSA values were adequate, indicating that the items were appropriate for factor analysis. Moreover, all the communality values were sufficient, indicating that the three suggested EO factors explained the variance in each item. These three factors explained $59 \%$ of the variance in total, and together with the Cronbach's alpha values being above the suggested cutoff value of 0.7 , the factor analysis indicated reliability with sufficiently valid factors.

We used the measure of human capital developed by Youndt et al. (2004) to evaluate employees' general levels of knowledge and skills. The questions focus on two main areas related to (1) the skills and expertise of the employees and (2) their creativity and level of new ideas (see Appendix). Our factor analysis supported this suggested structure and resulted in two dimensions (see Table 2). The MSA measures were sufficient $(>0.8)$, indicating that the items were appropriate for factor analysis. The two factors together explained $71.7 \%$ of the total variance, and the communalities were again at an acceptable level, suggesting that the two-factored human-capital construct explained the variance in each item sufficiently. The Cronbach's alpha values for both factors further indicated sufficient reliability and validity, as evidenced by the intrafactor correlations.

We combined the four SI items to form a single SI factor, explaining $65.6 \%$ of the total variance. The second, third, and fourth items were dropped due to a poor fit to the factor. The second factor had a communality of 0.48 , which suggests that SI did not 
Table 2 Rotated factor patterns for the applied measures

\begin{tabular}{|c|c|c|c|c|c|}
\hline & \multicolumn{5}{|c|}{ Entrepreneurial orientation } \\
\hline & Innovativeness & Risk-taking & Proactiveness & Comm. & MSA \\
\hline EO1 & 0.568 & & & 0.560 & 0.88 \\
\hline EO4 & 0.843 & & & 0.764 & 0.85 \\
\hline EO7 & 0.562 & & & 0.595 & 0.90 \\
\hline $\mathrm{EO} 2$ & & 0.682 & & 0.591 & 0.83 \\
\hline EO8 & & 0.654 & & 0.503 & 0.87 \\
\hline EO9 & & 0.526 & & 0.512 & 0.88 \\
\hline $\mathrm{EO} 3$ & & & 0.640 & 0.700 & 0.88 \\
\hline EO5 & & & 0.605 & 0.511 & 0.91 \\
\hline Var exp. & 0.222 & 0.195 & 0.174 & & \\
\hline Cum. var. & 0.222 & 0.418 & 0.592 & & \\
\hline Cron. alpha & 0.796 & 0.753 & 0.708 & & \\
\hline \multicolumn{2}{|c|}{$\mathrm{H} 0$ for 3 factors is sufficient } & 0.564 & & & \\
\hline & Human capital & & & & \\
\hline & Skills and know-how & Creativity & Comm. & & MSA \\
\hline $\mathrm{HC} 1$ & 0.790 & & 0.762 & & 0.85 \\
\hline $\mathrm{HC} 2$ & 0.687 & & 0.574 & & 0.89 \\
\hline $\mathrm{HC} 4$ & 0.696 & & 0.665 & & 0.87 \\
\hline $\mathrm{HC} 3$ & & 0.914 & 0.995 & & 0.81 \\
\hline $\mathrm{HC} 5$ & & 0.625 & 0.591 & & 0.82 \\
\hline Var exp. & 0.388 & 0.329 & & & \\
\hline Cum. var. & 0.388 & 0.717 & & & \\
\hline Cron. alpha & 0.839 & 0.848 & & & \\
\hline \multicolumn{2}{|c|}{$\mathrm{H} 0$ for 2 factors is sufficient } & 0.362 & & & \\
\hline & & \multicolumn{3}{|c|}{ Degree of internationalization (DOI) } & \\
\hline DOI1 & & 0.957 & 0.916 & & 0.67 \\
\hline DOI2 & & 0.806 & 0.649 & & 0.88 \\
\hline DOI3 & & 0.933 & 0.870 & & 0.69 \\
\hline Var exp. & & 0.812 & & & \\
\hline Cum. var. & & 0.812 & & & \\
\hline \multirow{2}{*}{\multicolumn{2}{|c|}{ Cron. alpha }} & 0.924 & & & \\
\hline & & \multicolumn{3}{|c|}{ Service innovation } & \\
\hline SI1 & & 0.875 & 0.765 & & 0.68 \\
\hline SI5 & & 0.795 & 0.632 & & 0.73 \\
\hline SI6 & & 0.756 & 0.571 & & 0.76 \\
\hline Var exp. & & 0.656 & & & \\
\hline Cum. var. & & 0.656 & & & \\
\hline \multirow[t]{3}{*}{ Cron. alpha } & & 0.846 & & & \\
\hline & & Profitability & & & \\
\hline & & & Comm. & & MSA \\
\hline P1 & & 0.916 & 0.838 & & 0.79 \\
\hline P2 & & 0.980 & 0.961 & & 0.68 \\
\hline P3 & & 0.917 & 0.840 & & 0.79 \\
\hline Var exp. & & 0.880 & & & \\
\hline Cum. var. & & 0.880 & & & \\
\hline Cron. alpha & & 0.956 & & & \\
\hline
\end{tabular}


explain the variance in the item. Thus, the item was removed, resulting in sufficient MSA and communality values and, by extension, reliability and validity for the SI factor (see Appendix for the individual items).

DOI is described in the literature through several constructs, including international diversity, export intensity, geographical diversity, multi-nationality, the scale and scope of internationalization, international business intensity, and degree of internationalization (Cavusgil and Zou 1994; Sullivan 1994; Zahra and Garvis 2000; Zahra et al. 2000; Lu and Beamish 2001, 2004; Saarenketo et al. 2004; George et al. 2005; Pla-Barber and Escriba-Esteve 2006; Li 2007), but in general, it is considered to be the extent of a company's operations outside the home country (Ietto-Gillies 2009). The three DOI items in the survey formed a single factor. The communalities were at an appropriate level, and the factor explained $81.2 \%$ of the variance. The results of the factor analysis, shown in Table 2, support Sullivan's (1994) suggestion to operationalize the DOI measure through a multiple-item measure. A single-factor solution explained $81 \%$ of the total variance, with a Cronbach's alpha value of 0.92 and sufficient communality values, containing four items (see Appendix). Finally, a single-factor solution was also obtained for profitability, with similarly sufficient MSA and Cronbach's alpha values (see Table 2), thus making all of the respective measures suitable for use in the analysis.

Finally, we included several control variables into the survey, and subsequently to our analyses. Traditionally, the main factors that may impact internationalization of companies are related to their industrial sector and to their size (Pla-Barber and EscribaEsteve 2006). Therefore, inquired upon the industrial sector of the respondents in order to distinguish between primarily manufacturing, retail, and service companies, and subsequently re-coded the three groups into a control variable. We also controlled for the age of companies, as extant research has indicated it tends to impact performance and international sales of smaller, younger firms in particular (Reuber and Fischer 1997; Zahra 2003). We further controlled for international experience and industry experience of the respondents, due to their potential impact on both internationalization and innovation (Andersson 2000; Manolova et al. 2002; Reuber and Fischer 1997; Ruzzier et al. 2007).

The responses on the different item scales ranged as follows: EO from 4.3 to 5.2, human capital from 5.0 to 6.2, and DOI between 1.6 and 2.5. In addition, the SI items ranged from 4.2 to 5.5. The levels of DOI and SI in particular indicate that the companies in the sample seemed to prioritize innovating over further internationalization. Table 3 shows the inter-correlations between the variables used in our analysis and the standardized factor averages.

\section{Results}

We tested the hypotheses by means of structural equation modeling (SEM). The most common estimation procedure within SEM is maximum likelihood, which is used for small sample sizes of 50 and has generated valid results, although the appropriate sample size is usually between 100 and 200. The significance level should be dropped to 0.025 or 0.01 with smaller sample sizes due to certain statistical characteristics of maximum likelihood estimation (Hair et al. 1998, p. 605; p. 613). The path model of profitability was based on the regression analysis results. We used the lavaan.survey $\mathrm{R}$ 


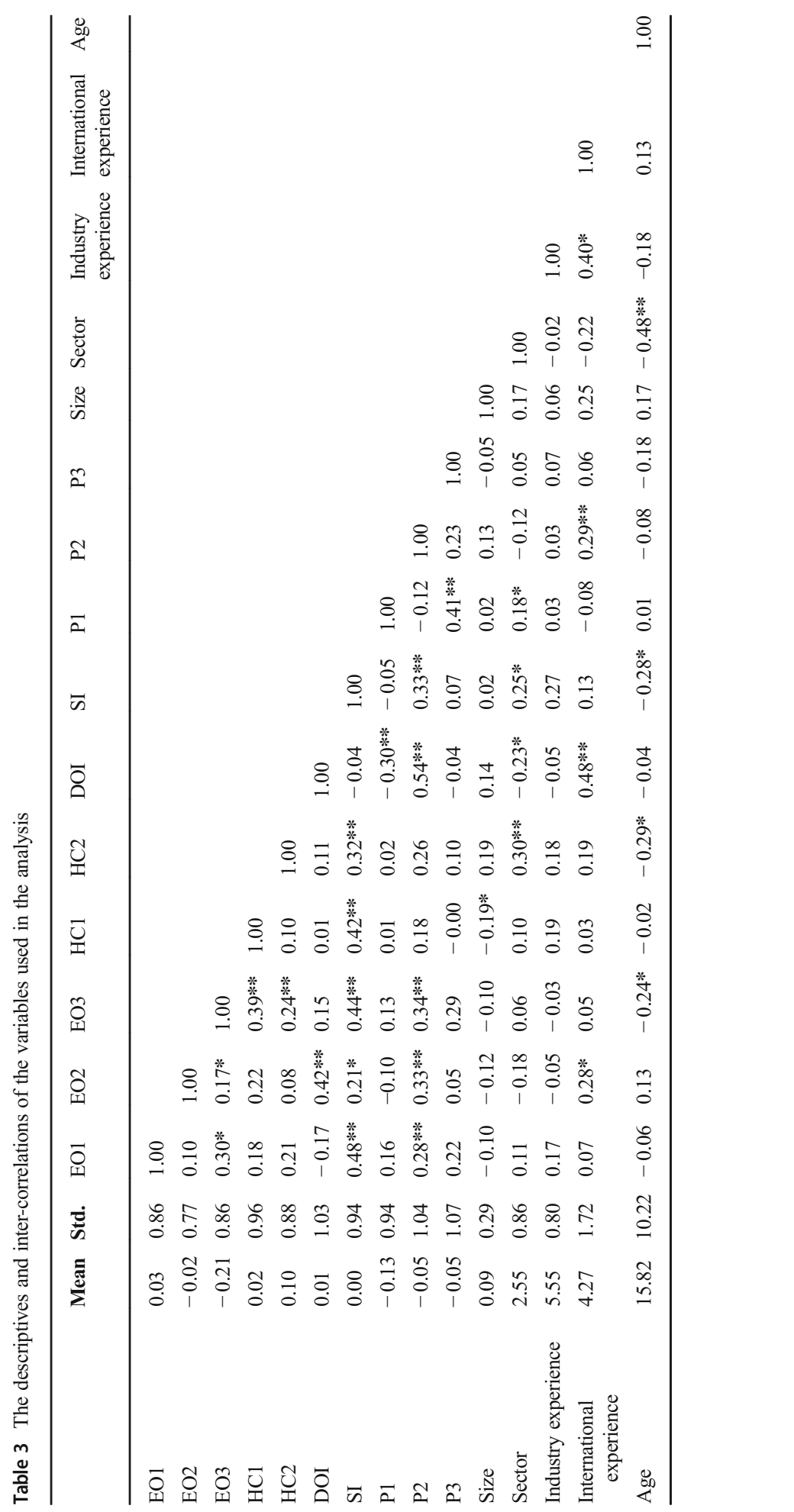


package for the SEM analyses. Three goodness-of-fit measures are used to evaluate the model fit in SEM: absolute fit, incremental fit, and parsimonious fit (Hair et al. 1998, p. 611; Hooper et al. 2008). The maximum likelihood method with robust standard errors was used for the model estimation. All the variables were standardized during the estimation due to the impact of normality, skewness, and kurtosis on the results, and the covariance matrix was generated via the software. Although the one-step model in which both confirmatory factor analysis and regression analysis is performed simultaneously is preferred, the two-step model has been widely used (Hair et al. 1998, p. 600).

Chi-square test statistics, and the ratio between chi-square $(\chi 2)$ and degrees of freedom (df) were used to evaluate the overall model fit. The value of the latter in the model with the profitability outcome was $0.835(15.022 / 18)$, suggesting no significant correlations between the matrices of the hypothesized model and the sampled data in the models of international performance and growth. The RMSEA value was 0.00 and thus below the suggested 0.08 threshold, indicating that errors in the fit of the covariance matrix were reasonable, although a good error of approximation was indicated in the profitability model. The SRMR value (0.04) was also below the recommended level of 0.08 , indicating that the model was not misspecified. All in all, the fit measures (CFI 1.000, TLI 1.027, RMSEA 0.000, and SRMR 0.040) in the profitability model indicated an adequate fit to the data (see Table 4). Both the CFI and TLI values were above 0.95 , suggesting a sufficient fit between the model and the sample data. This indicates that there was little possibility of measurement error because the difference between the null model and the sampled model was small. In addition, because all the measures in the model were at an adequate level, we checked that the SRMR values were between 0.06 and 0.03 , which lowers the likelihood of error.

Figure 1 depicts the overall model. The results give partial support to H1. Namely, the risk-taking dimension of EO (H1c) did have a positive and significant $(0.29$, sig. $<$ 0.01 ) impact on DOI. We did not consider this a surprising result given that entering foreign markets tends to require SMEs to focus their resources on internationalization, thus assuming a risk-taking strategic posture. The impact of innovativeness on DOI, although statistically significant, was nevertheless negative $(-0.19, \mathrm{sig} .<0.05)$. Thus, more innovation-oriented SMEs tended to exhibit lower levels of DOI, and H1a was not supported. The proactiveness dimension of EO was not associated with higher levels of DOI in the SEM model; thus, H1b was not supported either. In sum, the impact of EO on DOI was complex in that increased risk-taking led to higher levels of DOI, whereas a more innovative posture had the opposite effect.

Our second main hypothesis $(\mathrm{H} 2)$ postulated a positive impact of EO on SI. As Fig. 1 indicates, the results were similarly dependent on the EO dimension in question: the innovativeness dimension had a significantly positive impact $(0.35$, sig. $<0.01)$. Although this was not a surprising result in itself, we note that the impact was the opposite to that of DOI, suggesting that in assuming an innovative posture the SMEs were, in fact, prioritizing service innovation at the cost of expanding their international activities. Additionally, the risk-taking dimension of EO was not associated with SI, and the relationship of the proactiveness dimension, although positive, was nonsignificant $(0.22$, sig. $<0.05)$. Thus, H2 was partially supported through the support for $\mathrm{H} 2 \mathrm{a}$. 
Table 4 The results of the structural equation modeling with robust standard errors

Profitability

\begin{tabular}{|c|c|}
\hline \multicolumn{2}{|l|}{ DOI } \\
\hline EO1 & $\begin{array}{l}-0.188 * \\
(0.092)\end{array}$ \\
\hline $\mathrm{EO} 2$ & $\begin{array}{l}0.289 * * \\
(0.093)\end{array}$ \\
\hline Sector & $\begin{array}{l}-0.145 \\
(0.090)\end{array}$ \\
\hline Industry exp. & $\begin{array}{l}-0.262 * * \\
(0.095)\end{array}$ \\
\hline International exp. & $\begin{array}{l}0.532 * * \\
(0.096)\end{array}$ \\
\hline Age & $\begin{array}{l}-0.245 * \\
(0.101)\end{array}$ \\
\hline \multicolumn{2}{|l|}{ SI } \\
\hline EO1 & $\begin{array}{l}0.351 * * \\
(0.130)\end{array}$ \\
\hline $\mathrm{EO} 2$ & $\begin{array}{l}0.064 \\
(0.103)\end{array}$ \\
\hline $\mathrm{EO} 3$ & $\begin{array}{l}0.219 \\
(0.128)\end{array}$ \\
\hline $\mathrm{HC} 1$ & $\begin{array}{l}0.248 * \\
(0.125)\end{array}$ \\
\hline $\mathrm{HC} 2$ & $\begin{array}{l}0.170 \\
(0.140)\end{array}$ \\
\hline \multicolumn{2}{|l|}{ Performance } \\
\hline DOI & $\begin{array}{l}-0.330 * * \\
(0.124)\end{array}$ \\
\hline \multicolumn{2}{|l|}{ SI } \\
\hline \multicolumn{2}{|l|}{ Diagnostics } \\
\hline Min .func .test static & 15.885 \\
\hline Comparative Fit Index & 1.000 \\
\hline Tucker-Lewis Index & 1.027 \\
\hline RMSEA & 0.000 \\
\hline SRMR & 0.040 \\
\hline
\end{tabular}

Standard errors are in brackets

$R M S E A$ root mean square error of approximation, $S R M R$ standardized root mean square residual Statistical significance: $* 0.05$ and $* * 0.01$

The third hypothesis postulated a positive relationship between $\mathrm{HC}$ and DOI. As Fig. 1 indicates, higher levels of HC led to higher levels of SI rather than more extensive foreign operations. Thus, H3 was not supported. Conversely however, H4 was partially supported in that the skills and know-how dimension of HC was positively and significantly $(0.25$, sig. $<0.05)$ associated with higher levels of SI. The creativity dimension was positive $(0.17)$ but not statistically significant in our model. 


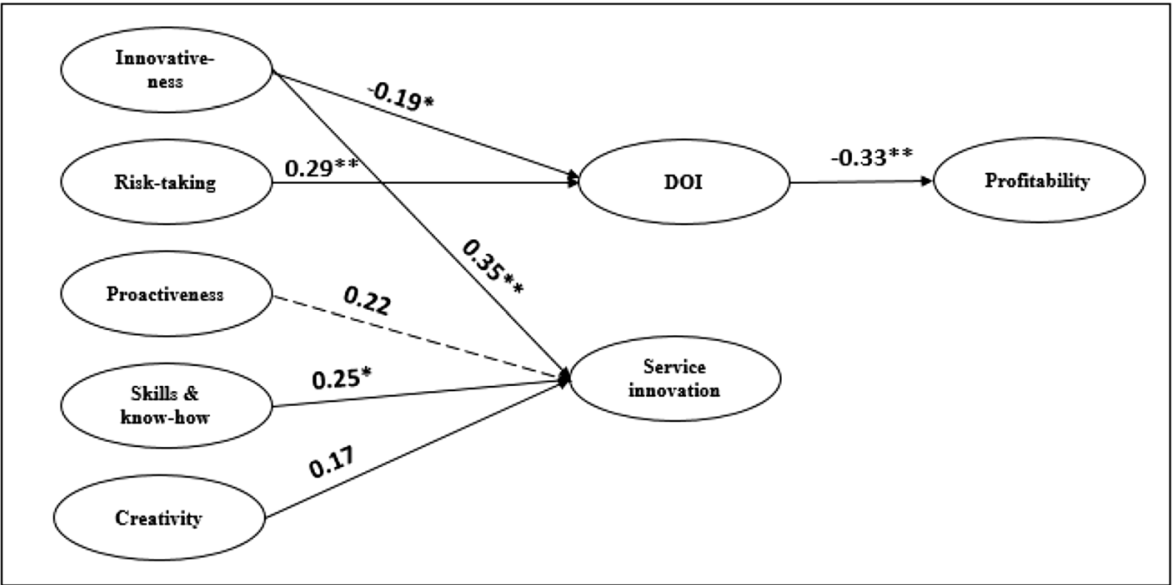

Note: $* \mathrm{P}<0.05, * * \mathrm{P}<0.01$

Fig. 1 The SEM path model

Finally, hypotheses H5 and H6 postulated a positive impact of SI and a negative impact of DOI (respectively) on the profitability of the international SMEs. As Fig. 1 shows, H6 was supported $(-0.33$, sig. $<0.01)$. In other words, higher levels of DOI among the companies led to decreased profitability, whereas SI was not associated to profitability in our model.

In sum, we conclude that the profitability model suggested a sufficient fit to the sample data, and thus indicated the following: the risk-taking dimension of entrepreneurial orientation positively and significantly affected DOI, and the innovativeness and proactiveness dimensions significantly and positively affected SI. Furthermore, according to the model, DOI was significantly negatively associated with profitability. Overall, the SEM results show that EO and HC may be antecedents of internationalization and service innovation among SMEs, but their respective impacts are largely contrary. The implication is that the aptitude of SMEs to engage in either service innovation or internationalization may preclude them from achieving the other. The findings also indicate that SMEs may have to make a choice between innovating and internationalizing, and if they were to choose the latter, they may have to be prepared for a negative impact on their profitability. One reason for this may be that increasing DOI requires a risk-taking entrepreneurial attitude, which may result in an increased likelihood of market failure.

\section{Discussion and conclusion}

While entrepreneurial internationalization and innovation have been linked together in international entrepreneurship for a long time (e.g., Knight and Cavusgil 2004), studying the two jointly has recently started to gain steam in the IE field (e.g., Veglio and Zucchella 2015; Denicolai et al. 2015; Weerawardena et al. 2019). However, the role of service innovation in the international entrepreneurship domain overall has received little attention, and thus, the aim of this study was to seek empirical 
clarification concerning the antecedents and outcomes related to service innovation in the context of SME internationalization. The results of this study indicate, first, that entrepreneurial orientation underlies both internationalization and service innovation in SMEs, but that the impact depends partly on the EO dimension, as the innovativeness dimension of EO has significant but opposite effects on DOI and SI, suggesting a tradeoff between innovation and internationalization when it comes to the entrepreneurial culture in SMEs. This is an interesting result when contrasted to those of Genc et al. (2019), who found EO to mediate between internationalization and innovation outcomes. Contrary to that study, we did not find EO to have a mutually beneficial and enriching role in linking innovation and internationalization outcomes, rather that the individual components of EO predict (service) innovation and internationalization separately. This difference may be due to the fact that Genc et al. measured innovation performance through the number of patents owned, thus their study context was not service innovation specifically. In addition, while Saridakis et al. (2019) found more innovative firms to also export more, the results of the present study contradict that result, by finding that the innovativeness dimension of EO has positive effect only on the extent of service innovation, but a negative one on the degree of internationalization. We suggest that these results may be due to the fact that the relationship between innovation and internationalization can depend on the type of innovation in question (Saridakis et al. 2019). The present study suggests that with service innovation, there may be a trade-off between engaging in innovation and international expansion.

Human capital would be an antecedent to SI, but not to the degree of internationalization among the SMEs and, although increasing the scale and scope of internationalization resulted in lower profitability among the SMEs, engaging in service innovation did not incur profitability costs for them. Consequently, our findings also imply that accumulated human capital may have neither a direct nor an indirect association with the profitability of an internationalizing SME. Our analyses did not yield evidence of a relationship between SI and profitability, but we did find a negative relationship between DOI and profitability. In this, our results are in conflict with Qian and Li's (2003) finding of a positive impact of DOI on SME profitability, while confirming those reported by Lu and Beamish (2006) indicating that exporting has a positive impact on growth, but a negative one on profitability. This may imply that, as Zahra et al. (2000) suggest, the relationship depends on the characteristics of the firm.

The main contribution of this study is multi-faceted. First, in examining both service innovation and internationalization jointly in the SME context, we have highlighted their potential antecedents of entrepreneurial orientation and human capital, while at the same time as investigating an under-researched internationalization outcome in profitability. Thus, the study adds to the knowledge and arising discussion on the role of innovation in internationalizing SMEs (Genc et al. 2019; Saridakis et al. 2019; Vrontis and Christofi 2019; Weerawardena et al. 2019), while also extending the study by Bello et al. (2016) to account also for internationalization outcomes. Second, the findings contribute to the literature on the determinants of firm performance, and on the successful internationalization of high-technology SMEs (Bell 1995; Coviello and Munro 1997; Moen et al. 2004; Saarenketo et al. 2004; Vadana et al. 2019) — a context relevant in IE. In particular, our results enhance knowledge of service innovation in the context of internationally operating SMEs (cf. Weerawardena et al. 2019): SMEs 
concentrating on service innovation are able to gain certain benefits by operating internationally but accruing these benefits may be complex and depend on the strategic goals of the firm. A further contribution is to add to the body of knowledge on the determinants and outcomes of DOI, the findings thus far having been mainly inconclusive and conflicting. Given that DOI had a negative relationship with the profitability of internationally operating SMEs while SI did not, the main implication of our analysis is that, at least in the short run, SMEs may remain more profitable through innovation-rather than internationalization-related activities.

Our finding that different dimensions of EO act as antecedents of both DOI and SI provides further empirical support for the suggestion in the literature that EO should be conceptualized as a multidimensional construct (Naman and Slevin 1993; Frishammar and Andersson 2009; Miller 2011; Cadogan 2012; Lomberg et al. 2017). On the other hand and in conflict with some of the extant literature on the topic (e.g., Fletcher 2004; Knight and Cavusgil 2004; Genc et al. 2019; Saridakis et al. 2019), we found that different dimensions of EO had varying impacts on internationalization and service innovation, namely that innovativeness had a positive impact on SI, and a negative relationship with DOI. Our results suggest that innovativeness among top management may in fact decrease DOI, which could imply that innovative managers tend to focus on developing and commercializing innovations and therefore allocate more resources to the process of innovating. Consequently, a trade-off may present itself due to the limited resources SMEs possess, forcing them to spend less on engaging in internationalization.

Moreover, we distinguished a positive relationship between the proactiveness dimension of EO and SI, and between the risk-taking dimension and DOI. Surprisingly and contrary to what de Jong et al. (2003) and den Hertog (2010) suggest, in our analyses, risk-taking had no influence on SI. We believe this may be attributable to the fact that service innovations are carefully planned and researched, and that management risk-taking does not play a role. On the other hand, the lack of a significant relationship between proactiveness and DOI implies that international expansion in these companies may be more an act of risk-taking than a carefully considered strategic choice, which may further imply that in some cases, SMEs follow effectuation logic (Sarasvathy 2001) rather than strategic causality.

We also found a relationship between human capital (HC) and SI, but not between $\mathrm{HC}$ and DOI. Instead, international experience was positively related and industry experience negatively related with DOI. This suggests that top management's international experience may play a more crucial role in internationalization in these types of companies than employees' skills and capabilities. The role of international experience is acknowledged in the literature (e.g., Reuber and Fischer 1997; Manolova et al. 2002; Ruzzier et al. 2007), but in contrast to the results reported by Shane (2000), Westhead et al. (2001) and D'Angelo and Presutti (2019), our findings imply that industry experience may have a negative impact on DOI. In addition, overall educational level did not have a significant effect on SI or DOI, which contradicts Wang and Chang's (2005) suggestion that educational background could be a dimension of human capital. Although there may be several explanations for the contrasting result in the present study, it could have had something to do with the nature of the industry: many software SMEs are startups founded by students, university graduates, or serial entrepreneurs who may vary in educational background. 
In combination, the results regarding the effects of the EO dimensions and human capital on SI indicate that innovativeness among top management has a bigger impact than employee creativity in that the innovativeness dimension had a highly significant and positive relationship with SI, whereas in the case of creativity, the impact was only partially significant and positive. This could also imply that service innovations in SMEs tend to be created and developed from the top down, meaning that members of top management come up with new ideas that are then developed and commercialized together with employees. Furthermore, our findings also imply that SMEs may not be taking advantage of the potential of employees when assessing the role of skills and know-how in SI, or they may not see their creativity as beneficial. Notably, this could also imply that employees do not share their ideas sufficiently within the organization.

We also believe that our findings have relevant managerial implications. First, one could argue that the role of human capital in the development and commercialization of innovations is important. The human capital of both top managers and employees matters, although the creativity of employees matters less than their skills and knowhow. The implication here is that companies should perhaps focus more on applicants' skills and know-how rather than their creativity and innovativeness in the hiring process. Furthermore, the importance of international experience as well as skills and know-how in DOI and SI highlights the role of training and the opportunity to undertake international assignments. Second, as opposed to what is suggested in the literature, our findings do not support the adoption of a dual strategy combining innovation and internationalization, not at least if the internationalizing SME aims to maintain profitability. SMEs should therefore focus first either on innovation or on internationalization.

The main limitations of this study include its single-country and single-industry focus, which limits the generalizability of the results (cf. Bryman and Bell 2003 p. 105). The proposed model should subsequently be applied across industries, and a crosscountry study could reveal more about the potential generalizability of the results obtained. For example, Lomberg et al. (2017) have shown that in the case of lowand high-tech firms, the degree to which each dimension of EO explains the variance in performance differs. Our findings may be valid in the context of high-technology SMEs in the Scandinavian countries and in other small economies that are similar to Finland. They may also be relevant to knowledge-intensive SMEs aiming at international expansion as well as to start-ups, which tend to be innovative and eager to internationalize by nature. The use of panel data would also allow more detailed examination of the DOI-profitability relationship.

Second, the sample mainly comprised small service companies in the ICT industry. Another limitation and, consequently, a potential avenue for future research is that we did not account for the radicalness of service innovations. This could also require applying den Hertog's (2010) six-dimensional model of SI, given that we used the fourdimensional model on account of its fit to our specific empirical context (i.e., technology, which plays a central role in ICT companies, is at the center of the fourdimensional model). This study was conducted in a specific cultural environment, and EO in particular has been found to be influenced by culture (Lee et al. 2011). Expanding the empirical view to cultures other than Finland might provide us with more information on the dynamics of EO with SME innovation and internationalization. There is some evidence that in emerging markets, the role of institutions and 
institutional development may impact the dynamics of internationalization and innovation (e.g., Wu et al. 2016). In order to make further comparison, future research could thus assess the role of the institutional environment from the developed economies point of view. We also note that the $10 \%$ response rate in the empirical sample was not particularly high. Thus, we considered the possibility of biases arising from the response rate and, as Rutherford et al. (2017) recently found in their review, low response rates are not expected to bias results in the entrepreneurship domain.

For the future, the significance of international experience and the non-significance of human capital in the human-capital-DOI relationship imply that, if structured differently, human capital could yield more evidence about the association. The structure suggested by Huang (2003) and Neal (1995) could give further insight into these dynamics. Furthermore, including tacit and explicit technological knowledge in the measures instead of educational level could provide different evidence about the effect of human capital on DOI and SI.

Another potential future research avenue could be taking the unit of analysis to the individual level, as human capital has been found to lead to accumulating entrepreneurial and managerial competencies (Kungwansupaphan and Siengthai 2012), as well as to overall venture success (Hormiga et al. 2011; De Cleyn et al. 2014). Examining the mindset of SME managers on the innovation-internationalization behavior activities among SMEs, as both global mindset and global orientation may affect the behavior related to internationalization (Felício et al. 2013). Moreover, gender may also have an influence in the entrepreneurial intentions of individuals (Díaz-García and JiménezMoreno 2010) and thus by extension, on their individual entrepreneurial orientation (Goktan and Gupta 2013). While our study did not approach the examined phenomena from the point of view of the individuality or the gender of the respondents, extant studies do thus indicate that accounting for the gender of the entrepreneur might yield additional insight into constructs such as EO in this context. In addition, social capital could also be considered an antecedent of DOI and SI, given the recognition of the important role of relationships in contemporary literature on internationalization and innovation (e.g., Chesbrough 2011, p. 35; Johanson and Vahlne 2011). Moreover, service innovations tend to require collaboration between the service provider and the customer or other external parties (Alam and Perry 2002; Magnusson 2003; Kristensson et al. 2008; Kuusisto and Riepula 2011).

The dynamics of internationalization and innovation have recently gained attention in research on international entrepreneurship (e.g., Hagen et al. 2014; Onetti et al. 2012; Veglio and Zucchella 2015; Saridakis et al. 2019; Weerawardena et al. 2019). However, most of the extant research incorporating innovation and internationalization is still from the context of large companies (Cano-Kollmann et al. 2016). It is important to distinguish between different types of innovations in the context of internationalization (Denicolai et al. 2015; Saridakis et al. 2019). Thus, this study has sought to add to the knowledge on a type of innovation that extant research in IE has mostly neglected, service innovation, and to highlight the common antecedents and performance implications underlying service innovation and successful internationalization of SMEs in a joint setting.

Funding Information Open access funding provided by LUT University. 


\section{Appendix. Selected survey items}

Entrepreneurial orientation (adapted from Jantunen et al. 2005):

- We are among the first ones to implement progressive and innovative production processes and practices.

- The management of our company supports the projects that are associated with risks and expectations for returns higher than average.

- We actively observe and adopt the best practices in our sector.

- We actively observe the new practices developed in other sectors and exploit them in our own business.

- We recognize early on such technological changes that may have an effect on our business.

- We are unable to take on unexpected opportunities.

- We search for new practices all the time.

- In uncertain decision-making situations, we prefer bold actions as to make sure that possibilities are exploited.

- We allocate our resources continuously to new promising operation areas.

Human capital (Youndt et al. 2004):

- Our employees are highly skilled.

- Our employees are widely considered the best in our industry.

- Our employees are creative and bright.

- Our employees are experts in their particular jobs and functions.

- Our employees develop new ideas and knowledge

Degree of internationalization:

- Please estimate the percentage of your company's total sales which are attributable to foreign sales.

- Please estimate the percentage of your company's profits which are attributable to foreign profits.

- Please estimate the percentage of your company's customers who are considered foreign customers.

- Please estimate the percentage of your employees that are located outside of the company's home country.

Service innovation (Cooper and Kleinschmidt 1987):

- Our service(s) offer unique benefits to the customer, not offered by competitors.

- Our service(s) rely on technology, which has never been used in the industry before.

- Our service(s) are not radically different from competitor services.

- Our service(s) provide higher quality than the competitors.

- Our service(s) are highly innovative, replacing a vastly inferior alternative.

- Our service(s) offers solutions that are not possible to achieve with existing products. 


\section{Profitability:}

The following statements pertain to the performance of your firm during the past 3 years relative to companies in the same industry. Please compare your firm over the past 3 years relative to the companies in the same industry on the following criteria:

$1=$ Our performance is much worse than the companies in the same industry. $7=$ Our performance is much better than the companies in the same industry. $4=$ Our performance is equal to the companies in the same industry.

- Return on equity (ROE).

- Return on assets (ROA).

- Return on sales (ROS).

Open Access This article is licensed under a Creative Commons Attribution 4.0 International License, which permits use, sharing, adaptation, distribution and reproduction in any medium or format, as long as you give appropriate credit to the original author(s) and the source, provide a link to the Creative Commons licence, and indicate if changes were made. The images or other third party material in this article are included in the article's Creative Commons licence, unless indicated otherwise in a credit line to the material. If material is not included in the article's Creative Commons licence and your intended use is not permitted by statutory regulation or exceeds the permitted use, you will need to obtain permission directly from the copyright holder. To view a copy of this licence, visit http://creativecommons.org/licenses/by/4.0/.

\section{References}

Acs ZJ (1999) Small and medium-sized enterprises, technology, and globalization. In: Acs ZJ, Yeung B (eds) Small and Medium-Sized Enterprises in the Global Economy. the University of Michigan Press, Michigan, pp 1-11

Acs ZJ, Yeung B (1999) Conclusions: small and medium-sized enterprises in the global economy. In: Acs ZJ, Yeung B (eds) Small and Medium-Sized Enterprises in the Global Economy. the University of Michigan Press, Michigan, pp 164-174

Alam I (2006) Service innovation strategy and process: a cross-national comparative analysis. Int Mark Rev 23(3):234-254

Alam I, Perry C (2002) A customer-oriented new service development process. J Serv Mark 16(6):515-534

Andersson S (2000) The internationalization of the firm from an entrepreneurial perspective. Int Stud Manag Organ 30(1):63-92

Annavarjula M, Beldona S (2000) Multinationality-performance relationship: a review and reconceptualization. Int J Org Anal 8(1):48-67

Asemokha A, Musona J, Torkkeli L, Saarenketo S (2019) Business model innovation and entrepreneurial orientation relationships in SMEs: implications for international performance. J Int Entrep. https://doi. org/10.1007/s10843-019-00254-3

Atuahene-Gima K, Ko A (2001) An empirical investigation of the effect of market orientation and entrepreneurship orientation alignment on product innovation. Organ Sci 12(1):54-74

Autio E, Sapienza HJ, Almeida JG (2000) Effects of age at entry, knowledge intensity, and imitability on international growth. Acad Manag J 43(5):909-924

Avlonitis GJ, Papastathopoulou PG, Gounaris SP (2001) An empirically-based typology of product innovativeness for new financial services: success and failure scenarios. J Prod Innov Manag 18(5):324-342

Baker WE, Grinstein A, Perin MG (2019) The impact of entrepreneurial orientation on foreign market entry: the roles of marketing program adaptation, cultural distance, and unanticipated events. J Int Entrep. https://doi.org/10.1007/s10843-019-00257-0

Ballot G, Fakhfakh F, Taymaz E (2001) Firms' human capital, R\&D and performance: a study on French and Swedish firms. Labour Econ 8(64):443-462

Barney J (1991) Firm resources and sustained competitive advantage. J Manag 17(1):99-120 
Becker GS (1964) Human Capital. Columbia University Press, New York

Bell J (1995) The internationalization of small computer software firms: a further challenge to "stage" theories. Eur J Mark 29(8):60-75

Bell J, Crick D, Young S (2004) Small firm internationalization and business strategy. Int Small Bus J 22(1): $23-56$

Bello DC, Radulovich LP, Javalgi RRG, Scherer RF, Taylor J (2016) Performance of professional service firms from emerging markets: role of innovative services and firm capabilities. J World Bus 51(3):413424

Bloodgood JM, Sapienza HJ, Almeida JG (1996) The internationalization of new high-potential U.S. ventures: antecedents and outcomes. Entrepreneur Theory Pract 20(4):61-76

Brockman BK, Morgan RM (2003) The role of existing knowledge in new product innovativeness and performance. Decis Sci 34(2):385-419

Bryman A, Bell E (2003) Business research methods. Oxford University Press, New York

Cadogan JW (2012) International marketing, strategic orientations and business success. Int Mark Rev 29(4): 340-348

Cainelli G, Evangelista R, Savona M (2004) The impact of innovation on economic performance in services. Serv Ind J 24(1):116-130

Cainelli G, Evangelista R, Savona M (2006) Innovation and economic performance in services: a firm-level analysis. Camb J Econ 30(3):435-458

Calvo N, Villarreal O (2019) Internationalization as process of value distribution through innovation: polyhedral diagnosis of a "born global" firm. J Bus Ind Mark 34(3):561-574

Cano-Kollmann M, Cantwell J, Hannigan TJ, Mudambi R, Song J (2016) Knowledge connectivity: an agenda for innovation research in international business. J Int Bus Stud 47(3):255-262

Capar N, Kotabe M (2003) The relationship between international diversification and performance in service firms. J Int Bus Stud 34(4):345-355

Cavusgil ST, Knight G (2015) The born global firm: an entrepreneurial and capabilities perspective on early and rapid internationalization. J Int Bus Stud 46(1):3-16

Cavusgil ST, Zou S (1994) Marketing strategy-performance relationship: an investigation of the empirical link in export market ventures. J Mark 58(1):1-22

Cefis E, Marsili O (2006) Innovation premium and the survival of entrepreneurial firms in the Netherlands. In: Santarelli E (ed) Entrepreneurship, growth, and innovation. Springer Science and Business Media, New York, pp 183-198

Chae BK (2011) An evolutionary framework for service innovation: insights of complexity theory for service science. Int J Prod Econ 135(2):813-822

Chandler GN, Hanks SH (1994) Market attractiveness, resource-based capabilities, venture strategies, and venture performance. J Bus Ventur 9(4):331-349

Chesbrough HW (2011) Open services innovation: rethinking your business to grow and compete in a new era. Jossey-Bass, San Francisco

Chetty SK, Stangl L (2010) Internationalization and innovation in a network relationship context. Eur J Mark 44(11/12):1725-1743

Cohen WM, Levinthal DA (1990) Absorptive capacity: new perspective on learning and innovation. Adm Sci Q 35(1):128-152

Cooper RG, Kleinschmidt EJ (1987) New products: what separates winners from losers? J Prod Innov Manag 4(3):169-184

Costello AB, Osborne JW (2005) Best practices in exploratory factor analysis: four recommendations for getting the most from your analysis. Pract Assess Res Eval 10(7):1-9

Coviello N, Munro H (1997) Network relationships and the internationalisation process of small software firms. Int Bus Rev 6(4):361-386

Covin JG, Slevin DP (1989) Strategic management of small firms in hostile and benign environments. Strateg Manag J 10(1):75-87

Covin JG, Slevin DP (1990) New venture strategic posture, structure, and performance: an industry life cycle analysis. J Bus Ventur 5(2):123-135

Covin JP, Slevin DP (1991) A conceptual model of entrepreneurship as firm behavior. Entrepreneur Theory Pract 16(1):7-25

Covin JG, Green KM, Slevin DP (2006) Strategic process effects on the entrepreneurial orientation-sales growth rate relationship. Entrepreneur Theory Pract 30(1):57-81

D'Angelo A, Presutti M (2019) SMEs international growth: the moderating role of experience on entrepreneurial and learning orientations. Int Bus Rev 28(3):613-624 
Dai L, Maksimov V, Gilbert BA, Fernhaber SA (2013) Entrepreneurial orientation and international scope: the differential roles of innovativeness, proactiveness, and risk-taking. J Bus Ventur 29(4):511-524

Dakhli M, De Clercq D (2004) Human capital, social capital, and innovation: a multi-country study. Entrepreneur Region Dev 16(2):107-128

Damanpour F (1991) Organizational innovation: a meta-analysis of effects of determinants and moderators. Acad Manag J 34(3):555-590

Damanpour F, Wischnevsky JD (2006) Research on innovation in organizations: distinguishing innovationgeneration from innovation-adopting organizations. J Eng Technol Manag 23(4):269-291

Damanpour F, Walker RM, Avellaneda CN (2009) Combinative effects of innovation types and organizational performance: a longitudinal study of service organizations. J Manag Stud 46(4):650-675

de Brentani U (2001) Innovative versus incremental new business services: different keys for achieving success. J Prod Innov Manag 18(3):169-187

De Clercq D, Sapienza HJ, Crijns H (2005) The internationalization of small and medium-sized firms. Small Bus Econ 24(4):409-419

De Cleyn SH, Braet J, Klofsten M (2014) How human capital interacts with the early development of academic spin-offs. Int Entrep Manag J 11(3):599-621

de Jong JPJ, Bruins A, Dolfsma W, Meijaard J (2003) Innovation in service firms explored: what, how and why?. Strategic Study B200205. EIM Business \& Policy Research, Zoeter-meer

Delgado-Gomez JM, Remirez-Aleson M, Espitia-Escuer MA (2004) Intangible resources as a key factor in the internationalization of Spanish firms. J Econ Behav Organ 53(4):477-494

den Hertog P (2010) Managing service innovation: firm-level dynamic capabilities and policy options. Doctoral thesis. Amsterdam: the University of Amsterdam

Denicolai S, Hagen B, Pisoni A (2015) Be international or be innovative? Be both? The role of the entrepreneurial profile. J Int Entrep 13(4):390-417

Díaz-García MC, Jiménez-Moreno J (2010) Entrepreneurial intention: the role of gender. Int Entrep Manag J 6(3):261-283

Dichtl E, Koeglmayr H-G, Mueller S (1990) International orientation as a precondition for export success. J Int Bus Stud 21(1):23-40

Dimitratos P, Plakoyiannaki E (2003) Theoretical foundations of an international entrepreneurial culture. J Int Entrep 1(2):187-215

Dutta S, Bilbao-Osorio B (2012) The Global Information Technology Report 2012: Living in hyperconnected world. Online report. http://www3.weforum.org/docs/Global_IT_Re port_2012.pdf. Accessed 09 April 2013

Ecorys (2012). EU SMEs in 2012: at the crossroads. Annual report. http://ec.europa.eu/enterprise/poli cies/sme/facts-figures-analysis/performance-review/files/supporting-documents/2012/annual-report_en. pdf. Accessed 15 November 2012

Edelman LF, Brush CG, Manolova T (2005) Co-alignment in the resource-performance relationship: strategy as mediator. J Bus Ventur 20(3):359-383

Etemad H (2015) The promise of a potential theoretical framework in international entrepreneurship: an entrepreneurial orientation-performance relation in internationalized context. J Int Entrep 13(2):89-95

Ettlie JH (1983) Performance gap theories of innovation. IEEE Trans Eng Manag 30(2):39-52

Felício JA, Caldeirinha VR, Rodrigues R, Kyvik O (2013) Cross-cultural analysis of the global mindset and the internationalization behavior of small firms. Int Entrep Manag J 9(4):641-654

Fletcher D (2004) International entrepreneurship and the small business. Entrepreneur Region Dev 16(4):289305

Freel MS, Robson PJA (2004) Small firm innovation, growth and performance: evidence from Scotland and northern England. Int Small Bus J 22(6):561-575

Frishammar J, Andersson S (2009) The overestimated role of strategic orientations for international performance in smaller firms. J Int Entrep 7(1):57-77

Gadrey J, Gallouj F, Weinstein O (1995) New modes of innovation: how services benefit industry. Int J Serv Ind Manag 6(3):4-16

Gallie E-P, Legros D (2012) Firms' human capital, R\&D and innovation: a study of French firms. Empir Econ 43(2):581-596

Gallouj F, Weinstein O (1997) Innovation in services. Res Policy 26(4-5):537-556

Genc E, Dayan M, Genc OF (2019) The impact of SME internationalization on innovation: the mediating role of market and entrepreneurial orientation. Ind Mark Manag 82:253-264

George G, Wiklund J, Zahra SA (2005) Ownership and the internationalization of small firms. J Manag 31(2): $210-233$

Ghoshal S (1987) Global strategy: an organizing framework. Strateg Manag J 8(5):425-440 
Goktan AB, Gupta VK (2013) Sex, gender, and individual entrepreneurial orientation: evidence from four countries. Int Entrep Manag J 11(1):95-112

Golovko E, Valentini G (2011) Exploring the complementarity between innovation and export for SMEs' growth. J Int Bus Stud 42(3):362-380

Grimmer L, Miles MP, Grimmer M (2013) A research note on the effect of entrepreneurial orientation on small retailer performance: a resource-advantage perspective. Int Entrep Manag J 11(2):409-424

Hagen B, Denicolai S, Zucchella A (2014) International entrepreneurship at the crossroads between innovation and internationalization. J Int Entrep 12(2):111-114

Hair JF, Anderson RE, Tatham RL, Black WC (1998) Multivariate data analysis. Prentice-Hall, New Jersey

Harms R, Reschke CH, Kraus S, Fink M (2010) Antecedents of innovation and growth: analyzing the impact of entrepreneurial orientation and goal-oriented management. Int J Technol Manag 52(1/2):135-152

Hitt MA, Keats BW, DeMarie SM (1998) Navigating in the new competitive landscape: building strategic flexibility and competitive advantage in the $21^{\text {st }}$ century. Acad Manag Rev 12(4):22-42

Hooper D, Coughlan J, Mullen M (2008) Structural equation modelling: guidelines for determining model fit. Electron J Bus Res Methods 6(1):53-60

Hormiga E, Batista-Canino RM, Sánchez-Medina A (2011) The role of intellectual capital in the success of new ventures. Int Entrep Manag J 7(1):71-92

Huang L-H (2003) Industry-specific human capital, occupation and firm size: evidence from Taiwan. Small Bus Econ 20(3):205-218

Hudson W (1993) Intellectual capital: how to build it, enhance it, use it. John Wiley \& Sons, New York

Hult GTM, Snow CC, Kandemir D (2003) The role of entrepreneurship in building cultural competitiveness in different organizational types. J Manag 29(3):401-426

Hult GTM, Hurley RF, Knight GA (2004) Innovativeness: its antecedents and impact on business performance. Ind Mark Manag 33(5):429-428

Ietto-Gillies G (2009) Conceptual issues behind the assessment of the degree of internationalization. Transl Corp 18(3):59-83

Jantunen A, Puumalainen K, Saarenketo S, Kyläheiko K (2005) Entrepreneurial orientation, dynamic capabilities and international performance. J Int Entrep 3(3):223-243

Javalgi RG, Todd PR (2011) Entrepreneurial orientation, management commitment, and human capital: the internationalization of SMEs in India. J Bus Res 64(9):1004-1010

Jensen JJ, Van Den Bosch FA, Volberda HW (2006) Exploratory innovation, exploitative innovation and performance: effects of organizational antecedents and environmental moderators. Manag Sci 52(11): 1661-1674

Johanson J, Vahlne J-E (2011) Markets as networks: implications for strategy-making. J Acad Mark Sci 39(4): $484-491$

Jones MV, Coviello NE (2005) Internationalisation: conceptualising an entrepreneurial process of behaviour in time. J Int Bus Stud 36(3):284-303

Kafouros MI, Buckley PJ, Sharp JA, Wang C (2008) The role of internationalization in explaining innovation performance. Technovation 28(1):63-74

Karniouchina EV, Victorino L, Verma R (2006) Product and service innovation: ideas for future crossdisciplinary research. J Prod Innov Manag 23(3):274-280

Kimberly JR (1981) Managerial innovation. In: Nystrom PC, Starbuck WH (eds) Handbook of organizational design: volume 1: adapting organizations to their environments. Oxford University Press, New York, pp 84-104

Knight GA, Cavusgil ST (2004) Innovation, organizational capabilities, and the born-global firm. J Int Bus Stud 35(2):124-141

Kogut B (1985) Designing global strategies: comparative and competitive value-added chains. Sloan Manag Rev 26(4):15-28

Kristensson P, Matthing J, Johansson N (2008) Key strategies for the successful involvement of customers in the co-creation of new technology-based services. Int J Serv Ind Manag 19(4):474-491

Kuivalainen O, Sundqvist S, Servais P (2007) Firms' degree of born-globalness, international entrepreneurial orientation and export performance. J World Bus 42(3):253-267

Kuivalainen O, Saarenketo S, Puumalainen K (2012) Start-up patterns of internationalization: a framework and its application in the context of knowledge-intensive SMEs. Eur Manag J 30(4):372-385

Kungwansupaphan C, Siengthai S (2012) Exploring entrepreneurs' human capital components and effects on learning orientation in early internationalizing firms. Int Entrep Manag J 10(3):561-587

Kuusisto A, Riepula M (2011) Customer interaction in service innovation: seldom intensive but often decisive. Case studies in three business service sectors. Int J Technol Manag 55(1/2):171-186

Kuusisto J, Kuusisto A, Yli-Viitala P (2013) Service development tools in action. Serv Ind J 33(3-4):352-365 
Lazonick W (2005) The innovative firm. In: Fagerberg J, Mowery DC, Nelson RR (eds) The Oxford handbook of innovation. Oxford University Press, New York, pp 29-55

Lee SM, Lim S-b, Pathak RD (2011) Culture and entrepreneurial orientation: a multi-country study. Int Entrep Manag J 7(1):1-15

Li L (2007) Multinationality and performance: a synthetic review and research agenda. Int J Manag Rev 9(2): 117-139

Lieberman MB, Montgomery DB (1988) First-mover advantages. Strateg Manag J 9(5):41-58

Lomberg C, Urbig D, Stockmann C, Marino LD, Dickson PH (2017) Entrepreneurial orientation: the dimensions' shared effects on explaining firm performance. Enterp Theory Pract 41(6):973-998

Loth F, Parks T (2002) The impact of foreign operations in organizational performance. Int J Manag 19(3): $418-428$

Louart P, Martin A (2012) Small and medium-sized enterprises and their attitudes towards internationalization and innovation. Int Bus Res 5(6):14-23

Lu JW, Beamish PW (2001) The internationalization and performance of SMEs. Strateg Manag J 22(6/7): 565-587

Lu JW, Beamish PW (2004) International diversification and firm performance: the S-curve hypothesis. Acad Manag J 47(4):598-609

Lu JW, Beamish PW (2006) SME internationalization and performance: growth vs. profitability. J Int Entrep 4(1):27-48

Lumpkin GT, Dess GG (1996) Clarifying the entrepreneurial orientation construct and linking it to performance. Acad Manag Rev 21(1):135-172

Madsen TK, Servais P (1997) The internationalization of born globals: an evolutionary process? Int Bus Rev 6(6):561-583

Magnusson PR (2003) Benefits of involving users in service innovation. Eur J Innov Manag 6(4):228-238

Manolova TS, Brush CG, Edelman LF, Greene PG (2002) Internationalization of small firms: international factors revisited. Int Small Bus J 20(1):9-13

Marr B, Gray D, Schiuma G (2004) Measuring intellectual capital -what, why, and how. In: Bourne M, the handbook of performance measurement. Gee, London, pp 369-411

Martin DR, Horne DA (1995) Level of success inputs for service innovations in the same firm. Int J Serv Ind Manag 6(4):40-56

McDougall PP, Oviatt BM (2000) International entrepreneurship: the intersection of two research paths. Acad Manag J 43(5):902-906

Miller D (1983) The correlates of entrepreneurship in three types of firms. Manag Sci 29(7):770-790

Miller D (2011) Miller (1983) Revisited: a reflection on EO research and some suggestions for the future. Entrepreneur Theory Pract 35(5):873-894

Moen Ø, Gavlen M, Endresen I (2004) Internationalization of small, computer software firms: entry forms and market selection. Eur J Mark 38(9/10):1236-1251

Naman JL, Slevin DP (1993) Entrepreneurship and the concept of fit: a model and empirical tests. Strateg Manag J 14(2):137-153

Neal D (1995) Industry specific human capital: evidence from displaced workers. J Labor Econ 13(4):653669

OECD (2012) Share of countries in ICT-related patents filed under the PCT. Online statistics. http://www. oecd.org/sti/ieconomy/oecdkeyictindicators.htm. Accessed 09 April 2013

Oke A (2007) Innovation types and innovation management practices in service companies. Int J Oper Prod Manag 27(6):564-587

Oly Ndubisi N (2014) Entrepreneurship and service innovation. J Bus Ind Mark 29(6):449-453

Onetti A, Zucchella A, Jones MV, McDougall-Covin PP (2012) Internationalization, innovation and entrepreneurship: business models for new technology-based firms. J Manag Gov 16(3):337-368

Onkelinx J, Manolova TS, Edelman LF (2016a) The human factor: investments in employee human capital, productivity, and SME internationalization. J Int Manag 22(4):351-364

Onkelinx J, Manolova TS, Edelman LF (2016b) Human capital and SME internationalization: empirical evidence from Belgium. Int Small Bus J 34(6):818-837

Ordeñez de Pablos P (2004) Human resource management systems and their role in the development of strategic resources: empirical evidence. J Eur Ind Train 28(6):474 489

Ordeñez de Pablos P (2006) Transnational corporations and strategic challenges: an analysis of knowledge flows and competitive advantage. Learn Organ 13(6):544-559

Paswan A, D'Souza D, Zolfagharian MA (2009) Toward a contextually anchored service innovation typology. Decis Sci 40(3):513-540 
Pèrez-Luño A, Wiklund J, Cabrera RV (2011) The dual nature of innovative activity: how entrepreneurial orientation influences innovation generation and adoption. J Bus Ventur 26(5):555-571

Pla-Barber J, Escriba-Esteve A (2006) Accelerated internationalization: evidence from a late investor country. Int Mark Rev 23(3):255-278

Qian G (2002) Multinationality, product diversification, and profitability of emerging US small- and mediumsized enterprises. J Bus Ventur 17(6):611-633

Qian G, Li L (2003) Profitability of small- and medium-sized enterprises in high-tech industries: the case of the biotechnology industry. Strateg Manag J 24(9):881-887

Radulovich LP (2008) An empirical examination of the factors affecting the internationalization of professional service SMEs: the case of India. Doctoral thesis. Cleveland: Cleveland State University

Ramaswamy K, Kroeck KG, Renforth W (1996) Measuring the degree of internationalization of a firm: a comment. J Int Bus Stud 27(1):167-177

Rask M (2014) Internationalization through business model innovation: in search of relevant design dimensions and elements. J Int Entrep 12(2):146-161

Rauch A, Wiklund J, Lumpkin GT, Frese M (2009) Entrepreneurial orientation and business performance: an assessment of past researcg and suggestions for the future. Entrepreneur Theory Pract 33(3):761-787

Rennie M (1993) Global competitiveness: born global. McKinsey Quarter 4:45-52

Reuber RA, Fischer E (1997) The influence of the management team's international experience on the internationalization behaviours of SMEs. J Int Bus Stud 2(4):807-826

Rhee J, Park T, Lee DH (2010) Drivers of innovativeness and performance for innovative SMEs in South Korea: mediation of learning orientation. Technovation 30(1):65-75

Ripollès-Melià M, Menguzzato-Boulard M, Sànchez-Peinado L (2007) Entrepreneurial orientation and international commitment. J Int Entrep 5(3-4):65-83

Roberts PW, Amit R (2003) The dynamics of innovative activity and competitive advantage: the case of Australian retail banking, 1981 to 1995 . Organ Sci 14(2):107-122

Runyan R, Droge C, Swinney J (2008) Entrepreneurial orientation versus small business orientation: what are their relationships to firm performance? J Small Bus Manag 46(4):567-588

Rutherford MW, O'Boyle EH, Miao C, Goering D, Coombs JE (2017) Do response rates matter in entrepreneurship research? J Bus Ventur Insights 8:93-98

Ruzzier M, Antoncic B, Hisrich RD, Konecnik M (2007) Human capital and SME internationalization: a structural equation modeling study. Can J Adm Sci 24(1):15-29

Saarenketo S, Puumalainen K, Kuivalainen O, Kyläheiko K (2004) Dynamic knowledge-related learning processes in internationalizing high-tech SMEs. Int J Prod Econ 89(3):363-378

Sarasvathy SD (2001) Causation and effectuation: toward a theoretical shift from economic inevitability to entrepreneurial contingency. Acad Manag Rev 26(2):243-263

Saridakis G, Idris B, Hansen JM, Dana LP (2019) SMEs' internationalisation: when does innovation matter? J Bus Res 96:250-263

Schwens C, Zapkau FB, Bierwerth M, Isidor R, Knight G, Kabst R (2017) International entrepreneurship: a meta-analysis on the internationalization and performance relationship. Enterp Theory Pract. https://doi. org/10.1111/etap.12280: 1-35

Shan P, Song M, Ju X (2016) Entrepreneurial orientation and performance: is innovation speed a missing link? J Bus Res 69(2):683-690

Shane S (2000) Prior knowledge and the discovery of entrepreneurial opportunities. Organ Sci 11(4):448-469

Silva GM, Styles C, Lages LF (2017) Breakthrough innovation in international business: the impact of techinnovation and market-innovation on performance. Int Bus Rev 26(2):391-404

Sullivan D (1994) Measuring the degree of internationalization of a firm. J Int Bus Stud 25(2):325-342

Thomas DE, Eden L (2004) What is the shape of the multinationality-performance relationship? Multinatl Bus Rev 12(1):89-110

Thornhill S (2006) Knowledge, innovation and firm performance in high- and low-technology regimes. J Bus Ventur 21(5):687-703

Toivonen M, Tuominen M (2009) Emergence of innovations in services. Serv Ind J 29(7):887-902

Vadana II, Torkkeli L, Kuivalainen O, Saarenketo S (2019) The internationalization of born-digital companies. In: Chidlow A, Ghauri PN, Buckley T, Gardner EC, Qamar A (eds) The changing strategies of international business. Palgrave Macmillan, Cham, pp 199-220

Van de Ven A (1986) Central problems in the management of innovation. Manag Sci 32(5):590-607

Van Riel AC, Lemmink J, Ouwersloot H (2004) High-technology service innovation success: a decisionmaking perspective. J Prod Innov Manag 21(5):348-359

Veglio V, Zucchella A (2015) Entrepreneurial firms in traditional industries. Does innovation matter for International growth?. J Int Entrep 13(2):138-152 
Vrontis D, Christofi M (2019) R\&D internationalization and innovation: a systematic review, integrative framework and future research directions. J Bus Res. https://doi.org/10.1016/j.jbusres.2019.03.031

Wales WJ, Gupta VK, Mousa F-T (2013) Empirical research on entrepreneurial orientation: an assessment and suggestions for future research. Int Small Bus J 32(4):357-383

Wang W, Chang C (2005) Intellectual capital and performance in causal models: evidence from the information technology industry in Taiwan. J Intellect Cap 6(2):222-236

Weerawardena J, Salunke S, Knight G, Mort GS, Liesch PW (2019) The learning subsystem interplay in service innovation in born global service firm internationalization. Ind Mark Manag. https://oi. org/10.1016/j.indmarman.2019.05.012

Westhead P, Wright M, Ucbasaran D (2001) The internationalization of new and small firms: a resource-based view. J Bus Ventur 16(4):333-358

Wiig Aslesen H (2008) Prospective innovation challenges in the ICT sector. Europe Innova Report. https://ec. europa.eu/transparency/regexpert/index.cfm?do=groupDetail.groupDetailDoc $\& \mathrm{id}=13358 \&$ no=7. Accessed 10 Jan 2020

Wiklund J (1999) The sustainability of the entrepreneurial orientation - performance relationship. Entrepreneur Theory Pract 42(1):39-50

Wiklund J, Patzelt H, Shepherd DA (2009) Building an integrative model of small business growth. Small Bus Econ 32(4):351-374

Wu L, Wang C, Chen C, Pan L (2008) Internal resources, external networks, and competitiveness during the growth stage: a study of Taiwanese high-tech ventures. Entrepreneur Theory Pract 32(3):59-82

Wu J, Wang C, Hong J, Piperopoulos P, Zhuo S (2016) Internationalization and innovation performance of emerging market enterprises: the role of host-country institutional development. J World Bus 51(2):251263

Youndt MA, Snell SA (2004) Human resource configurations, intellectual capital, and organizational performance. J Manag Issues 16(3):337-360

Youndt MA, Subramaniam M, Snell SA (2004) Intellectual capital profiles: an examination of investments and returns. J Manag Stud 41(2):335-361

Zahra SA (2003) International expansion of U.S. manufacturing family businesses: the effect of ownership and involvement. J Bus Ventur 18(4):495-513

Zahra SA, Garvis DM (2000) International corporate entrepreneurship and firm performance: the moderating effect of international environmental hostility. J Bus Ventur 15(5/6):469-493

Zahra SA, Jennings DF, Kuratko DF (1999) The antecedents and consequences of firm-level entrepreneurship: the state of the field. Entrepreneur Theory Pract 24(2):45-65

Zahra SA, Ireland RD, Hitt MA (2000) International expansion by new venture firms: international diversity, mode of market entry, technological learning, and performance. Acad Manag J 43(5):925-950

Zahra SA, Ucbasaran D, Newey LR (2009) Social knowledge and SMEs' innovative gains from internationalization. Eur Manag Rev 6(2):81-93

Zhou KZ, Gao GY, Yang Z, Zhou N (2005) Developing strategic orientation in China: antecedents and consequences of market and innovation orientations. J Bus Res 58(8):1049-1058

Zhou L, Wu W-P, Luo X (2007) Internationalization and the performance of born-global SMEs: the mediating role of social networks. J Int Bus Stud 38(4):673-690

Zucchella A, Palamara G, Denicolai S (2007) The drivers of the early internationalization of the firm. J World Bus 42(3):268-280

Publisher's note Springer Nature remains neutral with regard to jurisdictional claims in published maps and institutional affiliations. 